\begin{tabular}{|c|c|c|c|}
\hline Eiszeitalter u. Gegenwart & $\mathbf{4 4}$ & $\begin{array}{c}16-19 \\
4 \mathrm{Fig} .\end{array}$ & Hannover 1994 \\
\hline
\end{tabular}

\title{
Examples of Weichselian environments: local versus regional developments
}

\author{
ELSE KOLSTRUP*)
}

Weichselian, climate, palaeoenvironment, frost mounds, fires, local conditions

\begin{abstract}
In this paper some factors of uncertainty to the reconstruction of ice age palaeoenvironments are discussed. The discussion uses two examples of development on land, namely the examples of frost mounds and fires, and emphasises the developments with relation to local versus regional environmental changes. It is demonstrated that a change in local, non-climatic factors can result in deposits which can be mistaken as being the result of climatic change. It is proposed that future investigations can provide much additional information on past environmental developments and their complex cause-effect relationships on land, but in order to make holistic reconstructions it is necessary to look out for the possible effects of both climatic and non-climatic developments when environmental changes are reconstructed.
\end{abstract}

\section{[Beispiele weichselzeitlicher Umweltbedingungen: lokale Entwicklungen im Gegensatz zu regionalen]}

Kurzfassung: In der vorliegenden Arbeit werden einige Unsicherheitsfaktoren bei der Rekonstruktion von PaläoUmweltbedingungen diskutiert. In der Diskussion werden zwei Beispiele aus dem terrestrischen Bereich angeführt, nämlich Frosthügel und Brände; wobei der Schwerpunkt der Untersuchungen auf dem Gegensatz von lokalen zu regionalen Umweltveränderungen liegt. Es wird demonstriert, daß lokale Veränderungen, die keine klimatischen Ursachen haben, Ablagerungen entstehen lassen können, die den Eindruck erwecken, als seien sie das Ergebnis klimatischer Veränderungen. Es wird festgestellt, daßs künftige Untersuchungen eine Fülle zusätzlicher Informationen über Paläo-Umweltentwicklungen und ihre komplexen Beziehungen hinsichtlich Ursache und Wirkung liefern können. Um aber schlüssige Rekonstruktionen machen zu können, ist es notwendig, mögliche Effekte sowohl klimatisch als auch nicht klimatisch induzierter Entwicklungen zu untersuchen.

\section{Introduction}

From various sources, such as for example deep sea cores and ice cores, it is known that temperature changes took place during the ice age, and by now a good temperature framework has been established (e. g. Johnsen et al., 1992). However, the temperature is only one environmental parameter, and it is becoming increasingly understood that if good palae-

*) Adress of the author: Frau Dr. E. Kolstrup, Mosevej 12 Blans, DK - 6400 Sønderborg, Denmark oenvironmental reconstructions are to be made, other environmental parameters will also have to be included with the reconstructions. In particular the developments that took place on land can give information on complex cause-effect interrelationships. In present landscapes there is a great diversity of environments and subenvironments, sometimes within short distance, and there is no reason to presume that there was less complexity in the past. Therefore, by increasing the efforts on palaeoenvironmental reconstruction from land deposits it may, apart from temperatures, also become possible to include and understand hydrology- and wind conditions, as well as various geological processes from different types of areas. In turn such factors can be seen in relation to soil, vegetation and fauna.

One of the problems in the reconstructions is that geological localities can be regarded as points in the landscape and that deposits from different localities can be difficult to correlate in time and with relation to their palaeogeographic development. Yet, it is crucial that deposits and phenomena that are used for reconstruction of a certain time span date from the same period, so that similar environments from different periods are not correlated in time.

In order to make realistic palaeoenvironmental reconstructions it is necessary to know how various phenomena develop under relatively stable climatic conditions today, and further to make qualified estimates of the geological effects of major climatic changes. In other words, if regularities of single environmental factors through time, as deduced from complex palaeosituations, are to be outlined, it is necessary to find out what could have taken place as a result of regional climatic changes on the one hand, and what could have happened owing to local developments that occured without climatic change on the other.

In the following, two examples are given of developments which might at first sight be taken as indications of climatic, i. e., regional change; but once additional information on underlying factors are inclucled with the interpretation, it appears that their development might equally well be interpreted as the result of local, site specific conditions. 


\section{The example of frost mounds}

The first example relates to the development and decay of frost mounds. From palaeogeographic investigations it is known that frost mounds existed during the last ice age in NW-Europe (DE Gans, 1981, PISSART, 1983, WATSON, 1977). Frost mounds of various kinds, such as pingos and palsas, develop and decay naturally within permafrost environmens today without changes of climatic conditions (MACKAY,

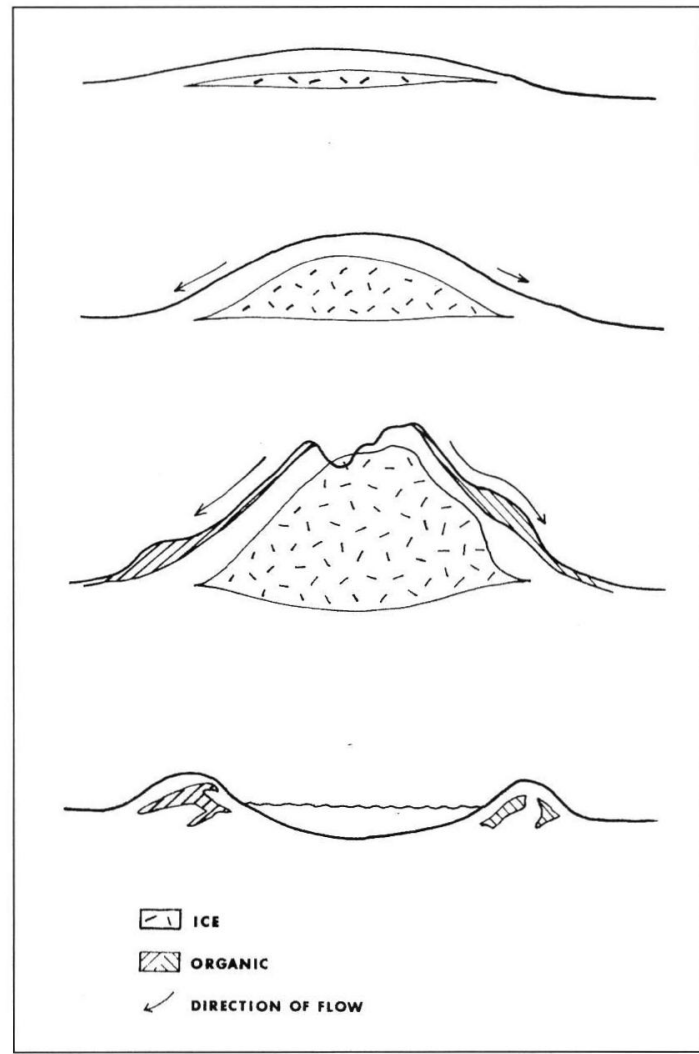

Figure 1: Scematic outline of growth and decay of a frost mound. The youngest part is at the top, and the age of the form increases downward of the figure.

1979). Figure 1 shows the scematic development of a frost mound under present periglacial conditions. Frost mounds have a core of ice, and with time this core grows in hight rather than in diameter (MACKAY, 1979). With time the sides become steeper, so that open cracks develop at the summit, and the sediment and vegetation on the sides become unstable and creeps/slumps downward where it accumulates along the perimeter of the form. Once the ice core has become exposed to the air and sun, melting occurs (MACKAY, 1979). When the ice core has melted, a lake remains surrounded by a ring wall, a rampart, of sediments and plant remains that originate from the sides of the pingo (MACKAY, 1986).
A pollen diagram from Stokersdobbe in the Netherlands (Fig. 2) represents a vegetation radiocarbon dated to around $18.000 \pm 200 \mathrm{BP}$ with dwarf birch,

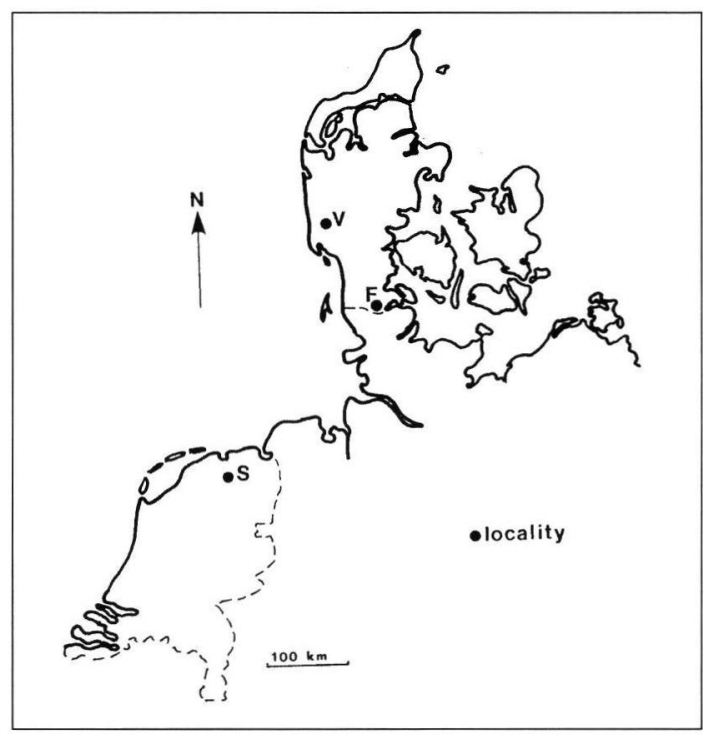

Figure 2: Location of Stokersdobbe (S), Frøslev (F) and Vittarp (V).

grasses, sedges and herbs (PARIS et al., 1979). A simplified version of this diagram is shown in Fig. 3. If no further information had been available from this locality it might have been suggested that this vege-

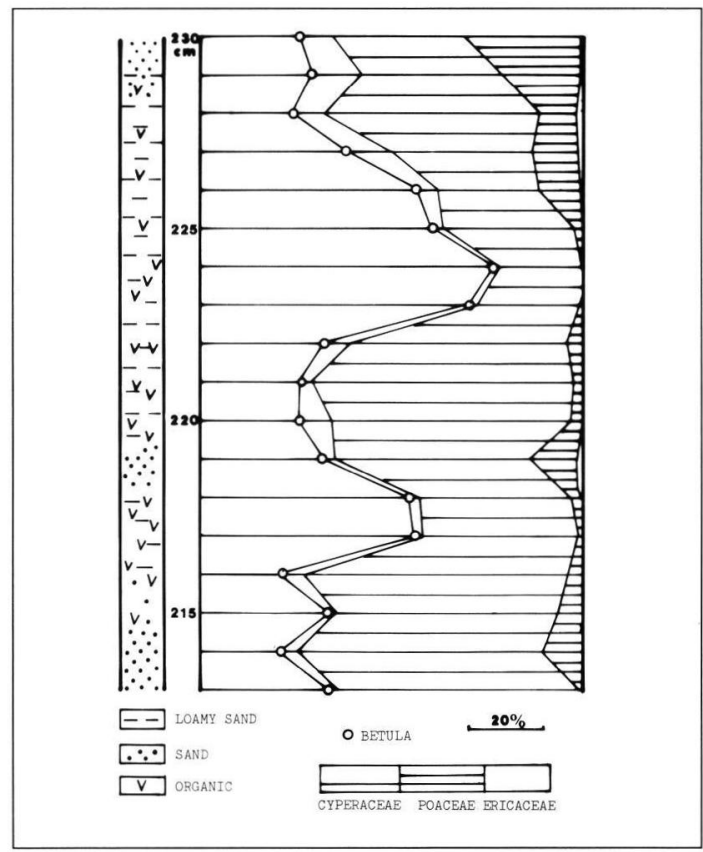

Figure 3: Simplified pollen diagram form Stokersdobbe. The depths are in $\mathrm{cm}$ above sea level. After PARIS et al. (1979). 
tation could represent a relatively warm phase between two colder periods. However, the geological information provided by PARIS et al. (1979) indicates that the organic material was found in a pingo rampart. Therefore it is probable that the vegetation represented by the pollen diagram should be seen as a slope product, which represents the time of pingo growth. The onset and termination of accumulation of organic material might consequently be interpreted as the result of a local phenomenon without change of climatic conditions.

This conclusion does not exclude the possibility of climatic change as an underlying factor for the development, but once there are natural, non-climatic alternative explanations to the reconstruction of a succession of events, a proposal of climatic change from such data needs additional evidence from contemporaneous comparable developments.

\section{The example of fires}

In the Taiga of NW-Canada and Alaska natural fires ignited by lightning occur regularly (VIERECK, 1983). This means that in areas with thunderstorms and presence of woody material, there is a possibility of fires and subsequent deposition of burnt organic material.

It is somewhat unusual to find traces of fires in ice age sediment, but during the last years, 3 Weichselian localities with burnt wood or charcoal particles have been found in Denmark.

One locality is located near Froslev in southern Denmark (Fig. 2). In that area large pieces of burnt wood of juniper (Juniperus) was found with regular intervals over some kilometers (Kolstrup \& Havemann, 1984). In most localities the wood was found within fluvial sediments and therefore redeposited, but in two localities it was found in situ overlain by aeolian sediment. Radiocarbon dates of c. 50.000 BP places the burning of a vegetation with juniper growth within the Weichselian.

In two localities near Varde in western Jutland microscopic charcoal particles were found during pollen countings of a deposit which may be of Odderade or post-Odderade age (Kolstrup 1992). A simplified pollen diagram from the locality, Vittarp 1 , is shown in Fig. 4. The diagram has some Pinus and Betula as well as Cyperaceae and Poaceae. Further there is presence of Calluna which has a maximum in sample 4 coinciding with a maximum of charcoal particles longer than $10 \mu \mathrm{m}$. Above that level the percentage of Pinus decreases and that of Betula increases. It is thought that a fire damaged the vegetation in the surroundings. Calluna which can reestablish itself relatively well after fires benefited from the fire in the competition with other taxa. It is possible that Pinus became damaged by the fire, and that the

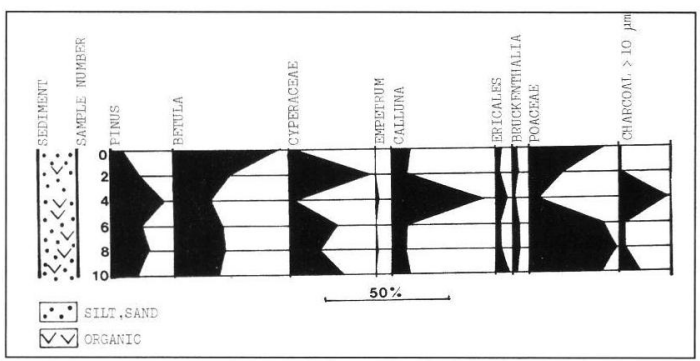

Figure 4: Simplified pollen diagram from Vittarp. After KOLSTRLP (1992).

change in the pollen diagram represents a change in the local vegetation after the fire. If that was the case, it means that changes in local vegetation and environment, could have taken place without change of climatic conditions. It is also possible that the termination of deposition of organic material might merely represent a supply of minerogenic sediment owing to exposed soil surfaces.

Also this kind of situation has consequences for the palaeoclimatic reconstruction; because, if accumulation of organic material was interrupted due to soil surface instability (in this case resulting from fire), it means that the reconstruction of past vegetational developments may turn out to be very complex, and that great care has to be taken when using, for example, the mutual AP and NAP pollen percentage relationship for climatic reconstruction (see also KOLSTRUP, 1990).

It follows that also the example with carcoal points to the necessity to include and integrate a number of contemporaneous developments in order to decide if a recorded change was the result of climatic or local change.

\section{The importance of dating}

The possibilities of alternative interpretations as to local versus regional palaeoenvironmental changes put a hard pressure on the available dating methods, but some results with relation to the present discussion have already been obtained. From radiocarbon datings it seems as if there is, for example, no longer a clustering of datings within what was previously thought to be Middle Pleniglacial interstadials. Instead the datings are more evenly distributed (RAN, 1990) an argument in favour of the idea of vegetations having been dependant on local conditions in addition to climatic change (see also KOLSTRUP, 1990).

Future investigations might, apart from the $14 \mathrm{C}$ method, also make use of the thermoluminescence and the optically stimulated light methods on Weichselian aeolian sediments collected at geologically thorougly investigated localities. 


\section{Conclusions}

The above examples are only single ones, and many more form other geological situations, such as for example dune slacks and abandoned stream channels, could have been mentioned. Besides, both the example of frost mound and fire are represented by single localities, and therefore they provide insufficient data to make general conclusions from. It follows that the present paper can only be regarded as a basis for discussion with relation to future systematic investigations. If such investigations can take into account the discussion on local versus regional conditions from land data for a number of localities, it may become possible to establish holistic pictures of past environments at a given time, and subsequently to arrange these pictures chronologically so that many-sided, detailed developments can be reconstructed. If such an approach of effect-cause relationship can be successfully made, it will lead to an improved understanding of the complexity that was also present in the nature of the past, and thereby it can serve as a strong tool in the prediction of future climatic and environmental changes.

\section{Acknowledgements}

I am very grateful to Dr. J. Klostermann who stimulated me to write this paper based on a lecture given at the DEUQUA meeting in Kiel and for his translation of the Kurzfassung. The field investigations that provided the Danish data were financially supported by the Carlsberg Foundation and the Danish Natural Science Research Council.

\section{References}

DE GANs, W. (1981): The Drentsche Aa valley system. A study in quaternary geology. Thesis Vrije Universiteit te Amsterdam. - Rodopi Amsterdam. 132 pp.

Johisen, S. J., Clausen, H. B., Dansgaard, W., Fuhrek, K., Gundestrup, N., Hammer, C. U., Iversen, P., Jouzel,
J., Stauffer, B. \& Steffensen, J. P. (1992): Irregular glacial interstadials recorded in a new Greenland ice core. - Nature, 359, 24th Sept: 311-313; London (Macmillan).

Kolstrup, E. \& Havemann, K. (1984): Weichselian Juniperus in the Froslev alluvial fan (Denmark). - Bulletin of the geological Society of Denmark 32: 121-131; Odense $(\mathrm{AiO})$.

KOLSTRUP, E. (1990): The puzzle of Weichselian vegetation types poor in trees. - Geologie en Mijnbouw 69: 253262. Dordrecht (Kluwer).

Kolstrup, E. (1992): Danish pollen records radiocarbondated to between 50000 and $57000 \mathrm{yr}$ BP. - Journal of Quaternary Science 7 (2): 163-172; Chichester (Wiley). Mackay, J. R. (1979): Pingos of the Tuktoyaktuk Peninsula area, Northwest Territories. - Géogr. phys. Quat. 33 (1): 3-61; Montreal (Les presses de l'Université).

MACKAY, J. R. (1986): Growth of Ibyuk Pingo, Western Arctic Coast, Canada, and some implications for environmental reconstructions. - Quaternary Research 26: 6880; Washington (Academic Press).

Paris, F. P., Cleveringa, P. \& De Gans, W. (1979): The Stokersdobbe: Geology and palynology of a deep pingo remnant in Friesland (The Netherlands). - Geologie en Mijnbouw 58 (1): 33-38; Dordrecht (Kluwer).

PISSART, A. (1983): Remnants of periglacial mounds in the Hautes Fagnes (Belgium): Structure and age of the ramparts. - Geologie en Mijnbouw 62: 551-555; Dordrecht (Kluwer).

RAN, E. T. H. (1990): Dynamics of vegetation and environment during the Middle Pleniglacial in the Dinkel valley (The Netherlands). - Mededelingen Rijks Geologische Dienst. 44-3: 141-205; Roermond (van der Marck).

Viereck, L. A. (1983): Vegetation. In: J. Brown \& R. A. Kreig (eds) Elliott and Dalton Highways, Fox to Prudhoe Bay, Alaska. - Guidebook to Permafrost and Related Features, 4th. International Conference on Permafrost, Fairbanks, Alaska: 26-31; Washington (National Academy Press).

Watson, E. (1977): The Periglacial Environment. The periglacial environment of Great Britain during the Devensian. - Phil. Trans. R. Soc. Lond. B. 280: 183-198; Great Britain.

Manuscript accepted 19. 11. 1992 